\title{
Tsunami hazard assessment in the southern Colombian Pacific basin and a proposal to regenerate a previous barrier island as protection
}

\author{
L. J. Otero ${ }^{1}$, J. C. Restrepo ${ }^{1}$, and M. Gonzalez ${ }^{2}$ \\ ${ }^{1}$ Physics Department, Universidad del Norte, Barranquilla, Colombia \\ ${ }^{2}$ Environmental Hydraulics Institute IH Cantabria, Santander, Spain
}

Correspondence to: L. J. Otero (ljotero@uninorte.edu.co)

Received: 20 March 2013 - Published in Nat. Hazards Earth Syst. Sci. Discuss.: 11 April 2013

Revised: 19 August 2013 - Accepted: 26 March 2014 - Published: 19 May 2014

\begin{abstract}
In this study, the tsunami hazard posed to 120000 inhabitants of Tumaco (Colombia) is assessed, and an evaluation and analysis of regenerating the previous El Guano Island for tsunami protection is conducted. El Guano Island was a sandy barrier island in front of the city of Tumaco until its disappearance during the tsunami of 1979; the island is believed to have played a protective role, substantially reducing the scale of the disaster. The analysis is conducted by identifying seismotectonic parameters and focal mechanisms of tsunami generation in the area, determining seven potential generation sources, applying a numerical model for tsunami generation and propagation, and evaluating the effect of tsunamis on Tumaco. The results show that in the current situation, this area is vulnerable to impact and flooding by tsunamis originating nearby. El Guano Island was found to markedly reduce flood levels and the energy flux of tsunami waves in Tumaco during the 1979 tsunami. By reducing the risk of flooding due to tsunamis, the regeneration and morphological modification of El Guano Island would help to protect Tumaco.
\end{abstract}

\section{Introduction}

When the source of an earthquake is entirely or partly under the sea, there is a risk of generating high-energy tidal waves of long period, which travel long distances at high speeds and, in some cases, cause severe damage to lives and property in coastal areas. These waves are known as tsunamis. Fortunately, not all seismic movements in the sea generate tsunamis. The occurrence of a tsunami depends on the parameters associated with the earthquake source, such as the type of tectonic shift (generally normal or reverse fault vertical movement of the seabed), the magnitude of the earthquake $\left(M_{\mathrm{S}}>5\right.$ on the Richter scale), the focal depth $\left(d_{\mathrm{f}}<50 \mathrm{~km}\right)$, and the source length $(L>100 \mathrm{~km})$ (Iida, 1970; Wiegel, 1970). Smaller sources can also generate destructive tsunamis, at least locally - for example, the 1990 Mariana earthquake and tsunami (Satake et al., 1992) or the outer-rise events modelled by Alvarez-Gomez et al. (2012).

Tsunamis are phenomena that occur infrequently but pose a greater hazard than earthquakes, hurricanes and tornadoes (Synolakis and Bernard, 2006; Birkmann et al., 2010). In the last 100 years, there has been an average of 10 tsunami events per year $(\eta<1 \mathrm{~m})$, one event per year of magnitude $1<\eta<5 \mathrm{~m}$, and one event every 17 years of magnitude $\eta>5 \mathrm{~m}$, all of which since 1850 have caused the loss of over 420000 lives and extensive damage to coastal infrastructure around the world (Bernard et al., 2006). On 26 December 2004 , in the coastal region of Indonesia, seabed movement generated a tsunami that reached more than $30 \mathrm{~m}$ in wave height along the adjacent coastal area and claimed the lives of more than 168000 people (Bernard et al., 2006). Just two hours after it was generated, this same event had already claimed the lives of an additional 63000 people in Thailand, Sri Lanka and India. There was another recent event on 11 March 2011, when a massive earthquake occurred in the Pacific off the coast of Tohoku, Japan. This earthquake and the resulting tsunami caused extensive damage in eastern Japan. The earthquake was of high magnitude $\left(M_{\mathrm{w}}=9.0\right)$, the highest recorded in Japan. The tsunami was also historic in terms of its $39 \mathrm{~m}$ height and large affected area. Approximately 24000 people were reported dead or missing (Mimura et al., 2011, Suppasri et al., 2012). 
The region of the North Andes block, specifically the seismic belt located off the Pacific coast of southern Colombia and northern Ecuador, is characterised by intense seismic activity (Gutscher et al., 1999; Collot et al., 2004). In this area during the last century, there were six major earthquakes with $M_{\mathrm{w}}>7.7$. The largest $\left(M_{\mathrm{w}}>8.6\right)$, which occurred on 31 January 1906, had an estimated rupture length of $500 \mathrm{~km}$ and was partially reactivated from south to north in the events of 14 May $1942\left(M_{\mathrm{S}}>7.9\right)$, 19 January $1958\left(M_{\mathrm{S}}>7.8\right)$ and 12 December $1979\left(M_{\mathrm{s}}>7.7\right)$ (Mendoza and Dewey, 1984; Beck and Ruff, 1984). These earthquakes were associated with tsunami generation, causing severe damage and the loss of human lives along the Colombian-Ecuadorian Pacific coast. The 1979 event affected a significant number of inhabitants in Tumaco (Fig. 1). The human and material damage caused by the 1979 earthquake-tsunami along the southern coast of Colombia from Tumaco to Guapi was considerable. In the department of Nariño alone, there were nearly 452 dead and 1011 injured, with approximately 3080 homes destroyed and more than 2100 damaged. Part of the Colombian coastline was changed dramatically by this tsunami. For example, the coastal town of San Juan located $60 \mathrm{~km}$ north of Tumaco was completely destroyed. The tsunami swept over the barrier island, destroying all the buildings and killing at least 220 people, mostly children. In the northwestern area of Tumaco, flooding was localised, and the barrier island of El Guano disappeared completely (Ramírez and Gover, 1980).

Natural hazards such as those caused by tsunamis are impossible to prevent; therefore, it is understandable that scientific and technical research is focused on studying vulnerability to these hazards and prevention-mitigation techniques to reduce that vulnerability, as the end objective is risk reduction. Accordingly, any preventive action taken prior, during or after the occurrence of a destructive natural phenomenon in an attempt to reduce its destructive consequences is called mitigation. Examples of mitigating actions are (1) the implementation of tsunami warning systems, (2) protective measures, and (3) adaptation measures.

Following the 1979 tsunami, efforts have focused on implementing solutions to minimise the risks to which the 120000 inhabitants in the town of Tumaco are exposed. However, despite these efforts, the risks remain high because much of the population lives in homes on the water built haphazardly without regard to earthquake-resistant standards (Fig. 1). Efforts have been directed towards two goals: (1) the development of an early warning system and (2) community training to understand the hazard and the need to move to safe areas in the city in the case of a tsunami warning.

Regarding the development of a tsunami warning system, the Tsunami Warning Centre (CAT by its initials in Spanish) has been in operation since 2008 at the facilities of the Pacific Oceanographic and Hydrographic Research Centre of Tumaco. This centre has fulfilled its monitoring role and has issued warnings of tsunami events, such as those in Chile in 2010 and Japan in 2011. However, should an

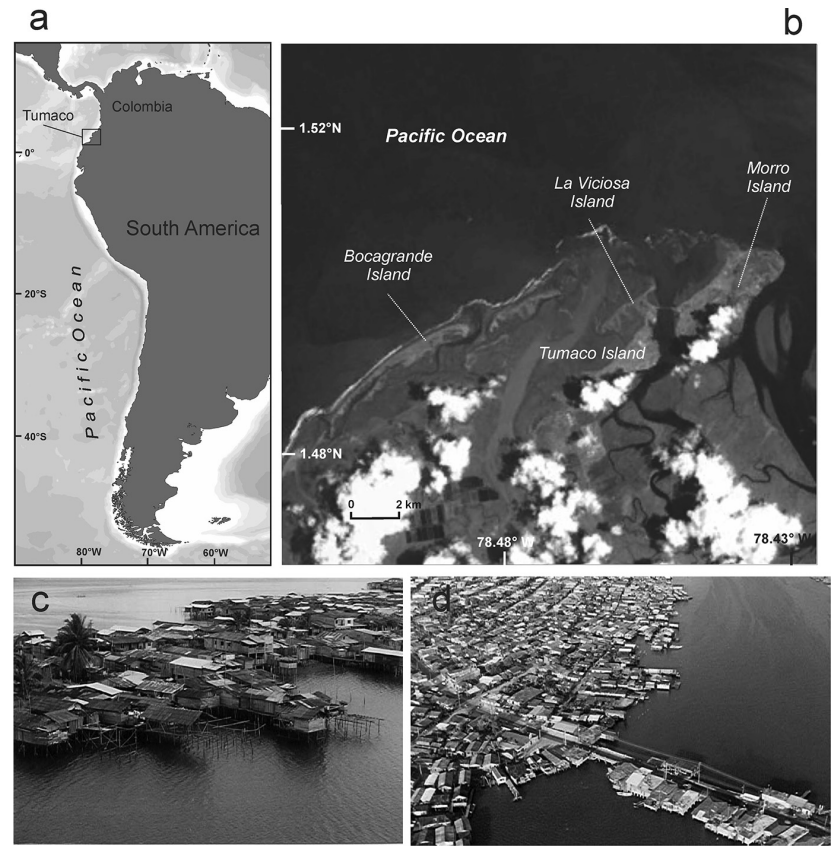

Fig. 1. (a) General location of Tumaco, (b) barrier island systems composing the municipality of Tumaco (adapted from Google Earth), and (c, d) type of housing and human settlements in Tumaco (Centro Control Contaminación del Pacífico photographs).

earthquake tsunami occur nearby, its effectiveness would be severely limited because the centre is located in the hazard zone. By contrast, efforts to educate and train the population of Tumaco to act in the case of a tsunami have been relatively successful; for example, five tsunami warning evacuation and safe-area mobilisation drills have been held since 2005. However, in the event of a nearby tsunami generated by an earthquake greater than $M_{\mathrm{w}}>8.0$ at high tide, the two islands where most of the population of Tumaco is concentrated would be completely flooded (Otero and González, 2004).

This study functionally analyses the regeneration of the former barrier island of El Guano (Fig. 2) and evaluates this regeneration as a realistic and feasible approach to mitigating the effects of tsunamis. This island disappeared during the 1979 tsunami but played a protective role during the event by substantially reducing the scale of the disaster. The tsunami experience in Indonesia showed that there are natural structures, such as beaches, dunes, mangroves, coral fields or groves, that help to significantly mitigate the effects of tsunamis (Tanaka et al., 2006, 2007; Tanaka, 2009). 

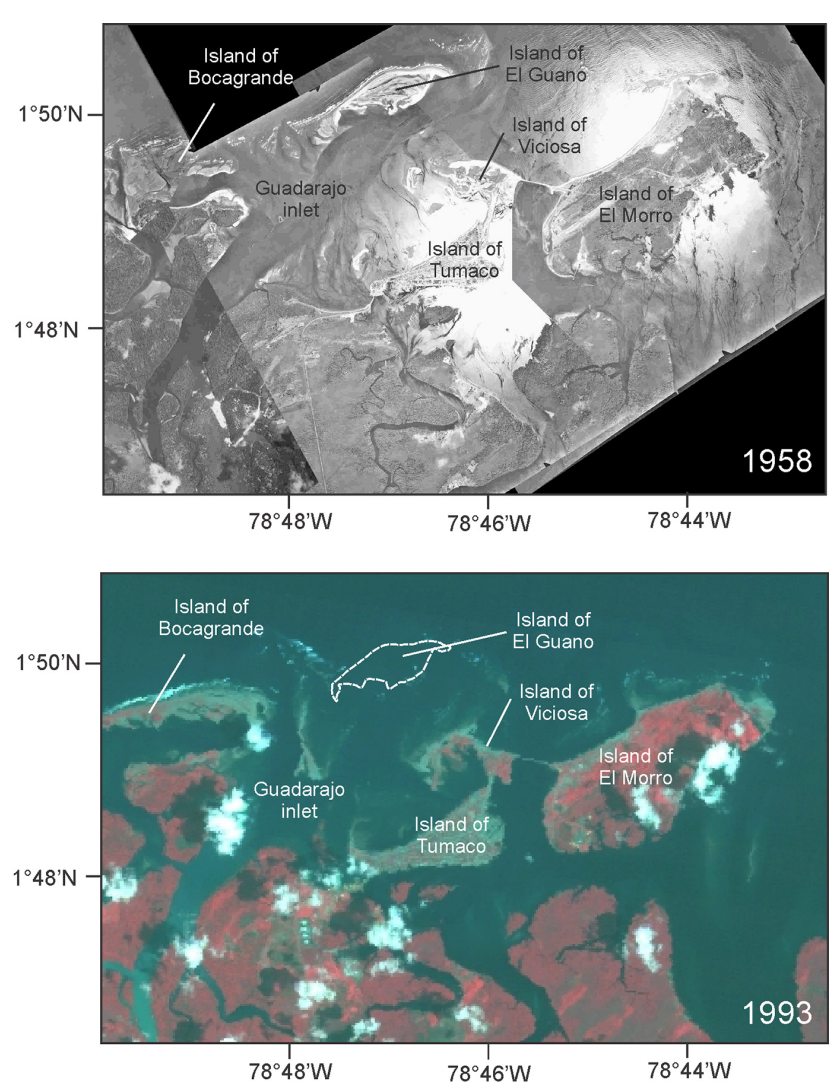

Fig. 2. Location of the El Guano barrier island before the 1979 tsunami event (top) and its current state (bottom).

\section{Study area}

\subsection{Tumaco Bay and the Mira River delta barrier island system}

Tumaco Bay is the largest bay on the Colombian Pacific coast with an area of $350 \mathrm{~km}^{2}$. The area inside the bay has shallow-water depths of less than $10 \mathrm{~m}$, but in the outer zone, the depth increases to $1000 \mathrm{~m}$ approximately $40 \mathrm{~km}$ from the edge of the continental shelf. The islands of Tumaco, El Morro and La Viciosa, which are located in the southwestern portion of the bay, form part of the barrier island system of the Mira River delta (Fig. 2). The subaerial surface of this delta covers $520 \mathrm{~km}^{2}$ and consists of seven distributaries, with the main discharge system located at Bocana Milagros. The mouth of the river is characterised by the presence of deltas and low-tide spits. By contrast, the rest of the delta has generated sandbars, areas of sand spit hook accretion, sand spits, and a barrier island system. The latter could be the result of the combined effects of the tidal range, littoral drift, sedimentary contributions of the Mira River, and differential displacements of tectonic blocks (e.g. Correa, 1996; Otero and Restrepo, 2008; Restrepo and López, 2008; Restrepo et al., 2008a). The Mira River delta is characterised by a semidiurnal tide and mesotidal tide range; the tidal range is $1.1 \mathrm{~m}$ during quadrature and during syzygy rises to 2.7 and $2.9 \mathrm{~m}$ in the southern and northern portions of the delta, respectively (Otero and Restrepo, 2008). The delta is also characterised by the presence of waves (in deep water) from the southwest and south-southwest, with significant heights ranging between 0.29 and $2.33 \mathrm{~m}$ and peak periods of $5-23 \mathrm{~s}$ (Restrepo et al., 2008b). The Mira River presents a bimodal hydrological pattern, with a mean annual flow of $868 \mathrm{~m}^{3} \mathrm{~s}^{-1}$ and maxima of 1105 and $965 \mathrm{~m}^{3} \mathrm{~s}^{-1}$ in May and December, respectively. The river is known for its discharge of suspended solids, estimated at $9.77 \times 10^{6} \mathrm{ta}^{-1}$ (Restrepo and Lopez, 2008).

\subsection{Seismic map of southwestern Colombia}

The northern Andean region is subjected to an intense crustal deformation, particularly in the Carnegie ridge formation subducted near Ecuador. The Carnegie ridge collision appears to have affected the coupling between the Nazca and the South American plates. Four large earthquakes have occurred on the northern flank of the collision zone (1906, 1942, 1958, and 1979) (Fig. 3). Collot et al. (2004) state that the subduction of the Nazca plate beneath the South American plate has produced one of the best examples of the variable behaviour of earthquake ruptures and conclude that there is a correlation between the boundaries of the coseismic rupture zones of the events of 1906, 1942, 1958 and 1979 and the geological structure of the area. Around the city of Tumaco, seismic activity is concentrated at depths between 20 and $40 \mathrm{~km}$, with reverse-type faults (dip-slip) (Gutscher et al., 1999); therefore, this area has been identified as an important area of tsunami generation and has, in fact, generated a tsunamigenic episode in each of the aforementioned seismic events.

The seismic source parameter most closely related to the tsunamigenic potential is the $M_{0}$ seismic moment (Kanamori and Anderson, 1975), which quantifies released seismic energy. In the case of the 1979 tsunami with a moment magnitude of $M_{\mathrm{w}}=7.9$, the seismic moment was $9.02 \times 10^{20} \mathrm{~N} \mathrm{~m}$ (Engdahl and Villaseñor, 2002), with a rupture length $(L)$ of $180 \mathrm{~km}$ (Beck and Ruff, 1984). These same authors suggest that the average vertical displacement of the fault was $5 \mathrm{~m}$. Regarding focal mechanisms, Engdahl et al. (1998) found that the 1979 earthquake had a $30^{\circ}$ fault plane strike $(\theta)$, a $16^{\circ}$ dip angle $(\delta)$, a slip angle $(\lambda)$ of $118^{\circ}$ and a depth $\left(h_{\mathrm{o}}\right)$ of $26.6 \mathrm{~km}$. These focal mechanisms are similar to those of the earthquakes that generated the tsunamis of 1906, 1942, and 1958 (Mendoza and Dewey, 1984; Beck and Ruff, 1984; Swenson and Beck 1996). Mendoza and Dewey (1984) and Collot et al. (2002) show that there are two parallel segments in the subduction zone between the Nazca and the Pacific tectonic plates. This subduction concentrates the most seismically active stretch of the Colombian-Ecuadorian zone, following the same pattern in a northeastern direction where the 


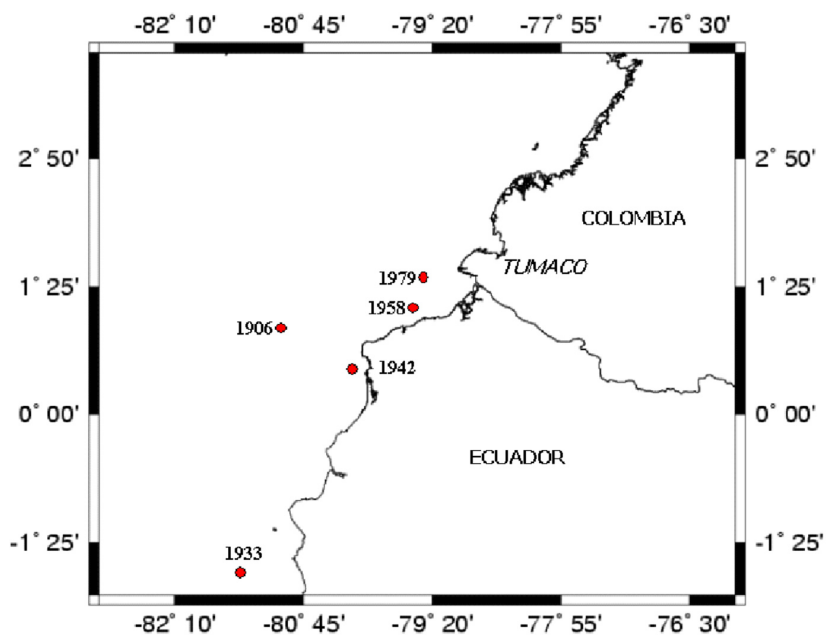

Fig. 3. Location of earthquake epicentres of historical tsunamis in the Colombian-Ecuadorian Pacific region.

epicentres of historical tsunamigenic earthquakes have also occurred (Fig. 4).

\section{Methods}

\subsection{Numerical model}

The numerical model used in this study is the COMCOT (Cornell multi-grid coupled tsunami model). This model is based on a finite-difference scheme and has been applied to investigate the effect of various historical tsunami events. These events include Chile in 1960 (Liu et al., 1994), Flores Island (Indonesia) in 1992 (Liu et al., 1995), the Indian Ocean in 2004 (Wang and Liu, 2006, 2007), Algeria in 2003 (Wang and Liu, 2005), and Lisbon in 1755 (Lima et al., 2010, Omira et al., 2011 and Baptista et al., 2011). Additionally, the model has been validated with benchmark cases defined within the European project "Tsunami Risk and Strategies for the European Region" (TRANSFER), contract No. 037058. The initial deformation of the sea surface that begins the propagation of tsunami waves is calculated using Okada's (1985) equations from fault rupture parameters. An instantaneous deformation completely transmitted to the seabed is assumed. Considering water as a noncompressible fluid, deformation is instantaneously transmitted to the surface of the sea.

The model solves linear and nonlinear shallow-water equations, adopting a modified leapfrog-type method. The ability of the model to incorporate nested meshes makes it possible to simulate the generation and propagation of tsunamis from the generation zone towards a specific area of the coast and to consider possible coastal flooding. The model adopts a moving boundary algorithm to simulate the variation in the coastline during flooding. In the Colombian-Ecuadorian Pacific region, tsunamis with wavelengths greater than $50 \mathrm{~km}$ can be expected, while the maximum sea depths are of the order of $3-4 \mathrm{~km}$. In these circumstances, the wave dynamics may be regarded as mainly horizontal, with negligible vertical accelerations; therefore, it can be assumed that the pressure fields are hydrostatic. The propagation of these waves can be correctly simulated using shallow-water equations. In a Cartesian coordinate system, these equations can be expressed as follows:

mass conservation equation:

$\frac{\partial \zeta}{\partial t}+\frac{\partial P}{\partial x}+\frac{\partial Q}{\partial y}=0$

momentum conservation equations:

$\frac{\partial P}{\partial t}+\frac{\partial P^{2}}{\partial x}+\frac{\partial P Q}{\partial y}+g H \frac{\partial \zeta}{\partial x}+\tau_{x} H-f Q=0$
$\frac{\partial Q}{\partial t}+\frac{\partial P Q}{\partial x}+\frac{\partial Q^{2}}{\partial y}+g H \frac{\partial \zeta}{\partial y}+\tau_{y} H-f P=0 ;$

where $\zeta$ is the free-surface elevation above mean sea level; $x$ and $y$ represent the longitude and latitude of the earth, respectively; $\tau_{x}$ and $\tau_{y}$ are the bottom friction stresses on the $x$ axis (to the east) and the $y$ axis (north), respectively; $P$ and $Q$ are discharge volumes $(P=H u$ and $Q=H v$, with $u$ and $v$ being average depth velocities in the longitudinal and latitudinal directions, respectively); and $H$ is the total water depth $(H=h+\zeta)$, with $h$ being the water depth, $f$ representing the Coriolis parameter, and $g$ being the acceleration due to gravity. In this study bottom friction was taken into account through the Manning coefficient. The value was fixed in 0.025 .

\subsection{Seismic scenarios}

To define these scenarios the records of the seismic Harvard centroid-moment tensor (Global CMT) catalogue (Harvard University, 2010) and the National Earthquake Information Center of the United States Geological Survey (NEICUSGS) (USGS, 2010) were reviewed. From these records, earthquakes caused by normal or reverse faults with $M_{\mathrm{w}}=$ 5.0 magnitudes and hypocentres between 15 and $70 \mathrm{~km}$ characterising the 40 years of major Pacific region seismic events were selected (Table 1). These events define the range of variation in the geometric parameters of earthquake faults able to generate tsunamis. Regarding fault plane strike, there are two groups with typical values between $0-45^{\circ}$ and $230-357^{\circ}$. The second group is characterised by lower magnitude events $\left(M_{\mathrm{w}} \leq 5.9\right)$. The dip angle presents a range of $15-36^{\circ}$, while the slip angle for the majority of values is between 104 and $138^{\circ}$ (Table 1).

Based on the range in variation of the geometric parameters from studies of historical tsunamis occurring along the Colombian Pacific coast (e.g. Beck and Ruff, 1984; Mendoza and Dewey, 1984; Gutscher et al., 1999) and the geophysical 
Table 1. Normal or reverse-type seismic events with $M_{\mathrm{W}} \geq 5.0$ and $h=15-70 \mathrm{~km}$ recorded in the Colombian Pacific from 1976-2010 (Harvard CMT catalogue, NEIC-USGS).

\begin{tabular}{|c|c|c|c|c|c|c|c|}
\hline $\begin{array}{l}\text { Date } \\
\text { (yyyy/mm/dd) }\end{array}$ & $\begin{array}{r}\text { Longitude } \\
\left({ }^{\circ} \mathrm{W}\right)\end{array}$ & $\begin{array}{l}\text { Latitude } \\
\qquad\left({ }^{\circ} \mathrm{N}\right)\end{array}$ & $\begin{array}{r}\text { Strike } \\
\left({ }^{\circ}\right)\end{array}$ & $\begin{array}{r}\text { Dip } \\
\left({ }^{\circ}\right)\end{array}$ & $\begin{array}{r}\text { Slip } \\
\left({ }^{\circ}\right)\end{array}$ & $\begin{array}{r}\text { Depth } \\
(\mathrm{km})\end{array}$ & $\begin{array}{r}\text { Magnitude } \\
\left(M_{\mathrm{W}}\right)\end{array}$ \\
\hline 1976/04/09 & -79.89 & 0.79 & 32 & 22 & 136 & 19.4 & 6.6 \\
\hline 1977/08/08 & -77.78 & 6.93 & 287 & 19 & 25 & 15.0 & 5.4 \\
\hline $1978 / 08 / 02$ & -78.00 & 7.29 & 21 & 40 & 38 & 15.0 & 5.5 \\
\hline 1979/01/01 & -80.46 & 0.59 & 23 & 24 & 116 & 18.3 & 5.7 \\
\hline $1979 / 12 / 12$ & -78.81 & 2.32 & 30 & 16 & 118 & 19.7 & 8.1 \\
\hline $1979 / 12 / 13$ & -79.49 & 2.88 & 45 & 19 & 107 & 15.0 & 6.3 \\
\hline $1979 / 12 / 31$ & -79.71 & 1.93 & 31 & 21 & 129 & 15.0 & 6.0 \\
\hline 1980/01/07 & -79.06 & 2.74 & 30 & 15 & 114 & 15.0 & 5.3 \\
\hline $1980 / 01 / 26$ & -79.84 & $2, .52$ & 12 & 22 & 76 & 15.0 & 5.6 \\
\hline 1980/09/03 & -78.53 & 2.63 & 1 & 20 & 85 & 37.4 & 6.1 \\
\hline 1981/01/03 & -78.95 & 2.13 & 253 & 24 & -39 & 18.0 & 5.4 \\
\hline 1981/05/16 & -77.11 & 7.76 & 236 & 22 & 94 & 21.0 & 5.3 \\
\hline 1982/08/01 & -79.40 & 2.71 & 41 & 22 & 138 & 15.0 & 5.3 \\
\hline 1982/08/14 & -78.15 & 7.02 & 319 & 33 & 49 & 15.0 & 5.2 \\
\hline $1983 / 01 / 23$ & -77.57 & 6.66 & 358 & 39 & -20 & 15.0 & 5.2 \\
\hline 1983/04/07 & -82.54 & 7.80 & 311 & 22 & 113 & 20.0 & 5.9 \\
\hline $1983 / 11 / 22$ & -79.99 & 0.31 & 33 & 24 & 133 & 35.2 & 6.8 \\
\hline $1984 / 07 / 30$ & -79.35 & 2.58 & 35 & 33 & 121 & 44.5 & 5.1 \\
\hline 1985/06/10 & -78.99 & 3.24 & 32 & 19 & 125 & 26.0 & 5.5 \\
\hline 1986/01/19 & -80.06 & 0.44 & 31 & 22 & 116 & 40.0 & 5.0 \\
\hline 1987/01/13 & -78.90 & 5.68 & 0 & 72 & 170 & 15.0 & 6.0 \\
\hline 1987/03/06 & -77.77 & 0.10 & 198 & 20 & 118 & 15.0 & 6.4 \\
\hline 1988/09/20 & -77.68 & 4.99 & 14 & 18 & 104 & 24.1 & 5.8 \\
\hline $1988 / 11 / 26$ & -77.89 & 6.95 & 316 & 29 & -56 & 21.4 & 5.5 \\
\hline $1989 / 06 / 25$ & -79.92 & 0.81 & 27 & 25 & 120 & 16.0 & 6.3 \\
\hline 1990/08/11 & -78.15 & 0.01 & 323 & 45 & 53 & 15.0 & 5.3 \\
\hline $1990 / 08 / 25$ & -77.93 & 5.71 & 350 & 36 & 79 & 35.1 & 5.3 \\
\hline 1991/11/19 & -77.18 & 4.80 & 13 & 13 & 95 & 19.1 & 7.2 \\
\hline $1994 / 09 / 27$ & -79.32 & 2.65 & 357 & 37 & -114 & 15.0 & 5.3 \\
\hline $1996 / 04 / 27$ & -79.42 & 2.47 & 44 & 15 & 110 & 15.0 & 6.1 \\
\hline $1996 / 05 / 23$ & -77.56 & 6.06 & 349 & 8 & 82 & 15.9 & 5.7 \\
\hline 1996/11/04 & -77.21 & 7.47 & 188 & 43 & 42 & 15.0 & 6.3 \\
\hline 1997/09/09 & -77.82 & 5.47 & 338 & 28 & 40 & 24.1 & 5.1 \\
\hline $1997 / 10 / 05$ & -79.56 & 2.15 & 345 & 25 & -140 & 15.0 & 5.3 \\
\hline 2000/07/12 & -77.80 & 6.54 & 319 & 34 & -144 & 15.0 & 5.2 \\
\hline 2000/10/08 & -78.07 & 0.00 & 342 & 42 & 90 & 15.0 & 5.1 \\
\hline 2003/01/08 & -77.40 & 6.10 & 299 & 76 & 172 & 25.1 & 5.7 \\
\hline 2004/06/01 & -79.96 & 0.69 & 33 & 28 & 133 & 34.2 & 5.4 \\
\hline 2004/11/15 & -77.57 & 4.72 & 21 & 11 & 114 & 16.0 & 7.2 \\
\hline $2006 / 01 / 23$ & -77.77 & 6.97 & 316 & 14 & 53 & 15.0 & 6.2 \\
\hline $2006 / 01 / 24$ & -77.73 & 6.96 & 307 & 29 & 50 & 23.7 & 5.4 \\
\hline 2006/01/29 & -77.82 & 6.88 & 313 & 23 & 58 & 27.0 & 5.2 \\
\hline 2007/09/22 & -77.53 & 6.06 & 8 & 20 & 90 & 20.3 & 5.0 \\
\hline 2008/10/02 & -77.95 & 5.76 & 100 & 72 & -12 & 23.7 & 5.0 \\
\hline
\end{tabular}

and seismic studies conducted in the Colombian-Ecuadorian region (e.g. Collot et al., 2004), an earthquake scenario has been defined for this study with geometric and focal characteristics (orientation, dip angle and dip direction of 23, 16 and $118^{\circ}$, respectively) similar to those of the earthquake of 12 December 1979. For the 1979 earthquake, Gutscher et al. (1999) defined the orientation, angle and dip orienta- tion conditions of 30,16 and $118^{\circ}$, respectively. Furthermore, the work of Mendoza and Dewey (1984) and Beck and Ruff (1984) show that the focal mechanisms for the seismic events of 1906, 1942 and 1958, which led to tsunamis, were similar to those of the 1979 event. The depth of the 1979 earthquake was also taken into account in defining the earthquake scenario $(h=19.7 \mathrm{~km})$ (Harvard University, 2010). 
To define the epicentres, historical events were included as references (e.g. Harvard University, 2010; USGS, 2010) as well as the work of Collot et al. (2004), which suggests based on seismic and geophysical evidence that the rupture area of the 1906 earthquake, revived by the 1942, 1958 and 1979 earthquakes, moves northwards in a SW-NE direction. From the spatial distribution of the earthquakes selected from the Global CMT (Harvard University, 2010) and NEIC-USGS (USGS, 2010) catalogues (Table 1), we can observe two main areas where the earthquakes with potential to generate tsunamigenic events are concentrated (Fig. 4). These areas form a line in a SW-NE direction parallel to the coastline and to the subduction zone. The outermost zone is located near the edge of the continental shelf in an area with depths approaching $2000 \mathrm{~m}$. The other area is located on the continental shelf in a region with depths up to $500 \mathrm{~m}$. This pattern has been confirmed by several geological and seismic studies conducted in the Colombian-Ecuadorian subduction zone (e.g. Mendoza and Dewey, 1984; Gutscher et al., 1999; Collot et al., 2004). The work conducted by Mendoza and Dewey (1984) and Collot et al. (2002) notes that there are two parallel segments in the subduction zone between the Nazca and Pacific tectonic plates where most of the seismic activity of the Colombian-Ecuadorian region is concentrated. These segments follow the same pattern in a NE direction. It is in this area where the epicentres of the large historical earthquake tsunamis are found (i.e. 1906, 1942, 1958 and 1979). Based on the spatial distribution of earthquakes with magnitudes $M_{\mathrm{w}} \geq 5.0$ that were caused by normal or reverse faults and had hypocentres between 15 and $70 \mathrm{~km}$ occurring in the Pacific region over the past 30 years (Table 1), and seismicity studies developed in this region (e.g. Beck and Ruff, 1984; Mendoza and Dewey, 1984; Gutscher et al., 1999; Collot et al., 2002), seven potential sources of tsunami generation for the southern Colombian Pacific coast (Fig. 5) have been identified. Table 2 shows the coordinates of the epicentres for each tsunami source.

Concerning the magnitude of the precursor earthquake, the Colombian Institute of Geology and Mining (INGEOMINAS by its initials in Spanish) concluded from assessments of the characteristics of the subduction segments of the Colombian Pacific coast that the Cabo Corrientes-Buenaventura segment is characterised by earthquakes of magnitude $M_{\mathrm{w}} \sim 7.0$ because the rupture zones cannot be large enough to generate events of greater magnitude. However, the BuenaventuraEsmeraldas segment (Ecuador) has the potential of generating earthquakes of greater magnitude, as occurred in 1906, 1942, 1958 and 1979, and these events were precursors to tsunamis (Cardona et al., 2005). Therefore, two scenarios with $M_{\mathrm{w}}=7.9$ and $M_{\mathrm{w}}=8.6$ are defined for this zone (Table 3), which correspond to the magnitudes of the earthquakes in 1979 and 1906, respectively (Gusiakov, 2001). These events have been the highest magnitude earthquakes recorded so far in this area (Mendoza and Dewey, 1984), so they are considered appropriate thresholds to assess the

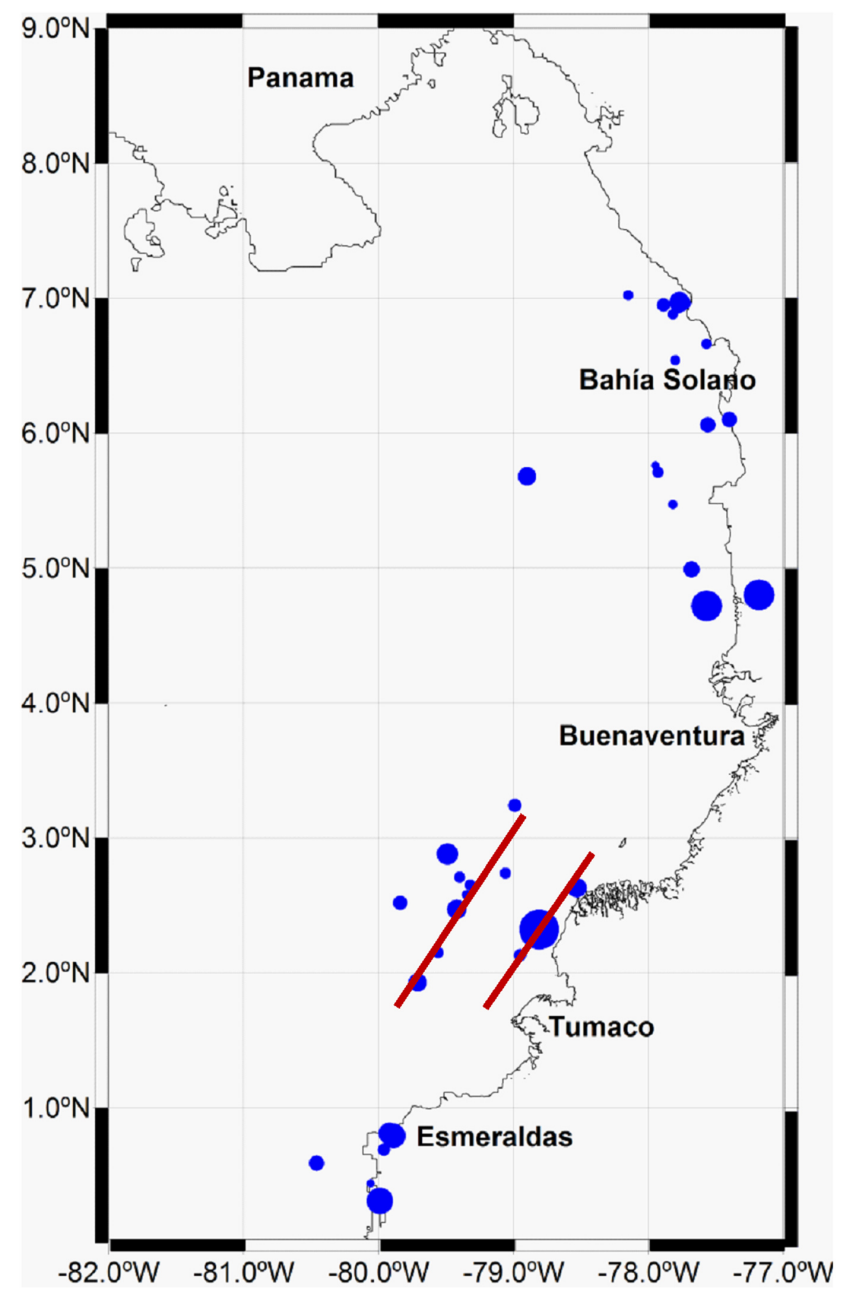

Fig. 4. Normal or reverse-type seismic events with $M_{\mathrm{W}}>5.0$ and $h=0-70 \mathrm{~km}$ recorded in the Colombian-Ecuadorian Pacific region from 1976 to 2010 . The area of the circles is proportional to the magnitude of the earthquake, with $M_{\mathrm{W}}=8.1$ for the large circle and $5<M_{\mathrm{W}}<8.1$ for the small circles (source, Harvard CMT catalogue; NEIC-USGS). The red lines indicate seismic patterns identified by Mendoza and Dewey (1984) and Collot et al. (2002).

tsunami hazard in the southern Colombian-Ecuadorian Pacific.

\subsection{DEM (digital elevation model) and tsunami source}

The epicentre that generated the 1979 tsunami event was located in Zone IV (Fig. 5). Figure 6 shows the islands composing the city of Tumaco and the points that have been selected for the temporal registration of simulated wave height and their comparative analysis. To simulate the 1979 event, the focal mechanisms computed by Engdahl et al. (1998) were used as shown in Table 3. The bathymetry around the islands of Tumaco existent prior to the event was available from historical nautical charts for the area. The bathymetry was obtained from the 2008 General Bathymetric Chart 


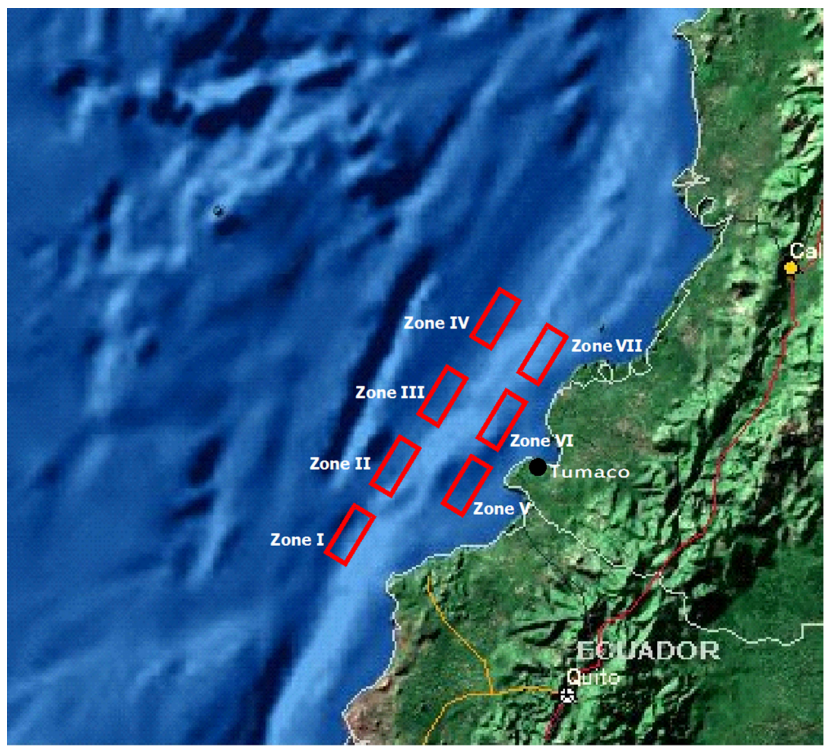

Fig. 5. Potential sources (epicentres) of tsunami generation for the southern Colombian Pacific coast defined from studies developed by Beck and Ruff (1984), Mendoza and Dewey (1984), Gutscher et al. (1999) and Collot et al. (2004).

of the Oceans (GEBCO), which corresponds to the entire Colombian-Ecuadorian Pacific basin. The tide level at the time of the event was $0.95 \mathrm{~m}$ (Otero and Gonzalez, 2004). For modelling the current situation, detailed coastal bathymetric surveys and available bathymetry were taken from nautical charts produced by the Colombian National Hydrographic Service. Figure 6 shows a calculation mesh scheme employed in numerical modelling. The cell size of each grid was chosen in order to keep CFL $\leq 0.5$. The topographic information was obtained from the National Geographic Institute of Colombia (IGAC by its initials in Spanish) and detailed topographic surveys conducted by the Centre for Pacific Oceanographic and Hydrographic Research.

The dimensions of the fault plane, which coincide with those determined by Beck and Ruff (1984) for the $1979 \mathrm{Tu}$ maco earthquake rupture process, were calculated using the relationship proposed by Wells and Coppersmith (1994) (Table 3). The bathymetry includes El Guano Island, which existed at the time. The simulations did not take into account the morphological changes of the Guano Island induced during the tsunami, because the COMCOT model has not a morphological evolution block. Thus, the effect of the island was taken into account through its geometric configuration and the bottom friction.

The same event was again simulated but omitting El Guano Island to investigate the consequences today for the city of Tumaco from the recurrence of a similar tsunamic event without the presence of this barrier island.

For the numerical simulation of future events, we have selected the most unfavourable conditions that can be expected.
Table 2. The coordinates of the epicentres for each tsunami sources in the Ecuadorian-Colombian South Pacific.

\begin{tabular}{llll}
\hline Source & $\begin{array}{l}\text { Longitude } \\
\left({ }^{\circ}\right)\end{array}$ & $\begin{array}{l}\text { Latitude } \\
\left({ }^{\circ}\right)\end{array}$ & $\begin{array}{l}\text { Depth } \\
(\mathrm{km})\end{array}$ \\
\hline Zone I & $-80.70^{\circ} \mathrm{W}$ & $1.00^{\circ} \mathrm{N}$ & 20 \\
Zone II & $-80.35^{\circ} \mathrm{W}$ & $1.50^{\circ} \mathrm{N}$ & 20 \\
Zone III & $-80.00^{\circ} \mathrm{W}$ & $2.00^{\circ} \mathrm{N}$ & 20 \\
Zone IV & $-79.50^{\circ} \mathrm{W}$ & $3.00^{\circ} \mathrm{N}$ & 20 \\
Zone V & $-79.40^{\circ} \mathrm{W}$ & $1.60^{\circ} \mathrm{N}$ & 20 \\
Zone VI & $-79.30^{\circ} \mathrm{W}$ & $2.00^{\circ} \mathrm{N}$ & 20 \\
Zone VII & $-79.00^{\circ} \mathrm{W}$ & $2.50^{\circ} \mathrm{N}$ & 20 \\
\hline
\end{tabular}

Table 3. Seismic scenarios defined for numerical modelling. The rupture area (i.e. length and width) and the magnitude of the dislocation are calculated from empirical relationships with $M_{\mathrm{w}}$ proposed by Wells and Coppersmith (1994).

\begin{tabular}{lrr}
\hline \multirow{2}{*}{ Parameters } & \multicolumn{2}{c}{ Magnitude scenarios } \\
\cline { 2 - 3 } & No 1 & No 2 \\
& (year 1979) & (year 1906) \\
\hline Dislocation $(\mathrm{m})$ & 4.5 & 10.0 \\
Rupture length $(\mathrm{km})$ & 200.0 & 400.0 \\
Rupture width $(\mathrm{km})$ & 80.0 & 160.0 \\
Strike $\left(^{\circ}\right)$ & 23.0 & 23.0 \\
Dip angle $\left(^{\circ}\right)$ & 16.0 & 16.0 \\
Slip angle $\left(^{\circ}\right)$ & 118.0 & 118.0 \\
Depth $(\mathrm{km})$ & 20.0 & 20.0 \\
Magnitude $\left(M_{\mathrm{W}}\right)$ & 7.9 & 8.6 \\
\hline
\end{tabular}

Establishing the 1906 event as the most credible worst event but having this event occur at high tide, i.e. an event with magnitude $M_{\mathrm{W}}=8.6$, would produce a rupture area $\left(A_{\mathrm{r}}\right)$ of $68000 \mathrm{~km}^{2}$, a rupture length $(L)$ of $400 \mathrm{~km}$, and a vertical dislocation $(D)$ of $10 \mathrm{~m}$ with a sea level corresponding to $5 \%$ exceedance (level $=+3.6 \mathrm{~m}$ ) (Otero and Restrepo, 2008). The results of this simulation are useful to evaluate the benefit of restoring El Guano Island to protect the population living in Tumaco under the worst credible scenario. The generation and propagation of tsunami events corresponding to generation areas are conducted taking into account the focal parameters, the generation mechanisms and the calculation conditions shown in Table 3. The simulations included two situations: (1) in the absence of El Guano barrier island and (2) in the presence of El Guano barrier island.

To evaluate the efficiency of the El Guano barrier island in mitigating the impact of tsunamis, a comparison was made between energy flux associated with the maximum wave height and the tsunami wave velocity in situations with and without the barrier island at the recording points shown in Fig. 6. According to the linear theory, the total energy flux of a long wave can be expressed as

$E_{\mathrm{f}}=E C$, 


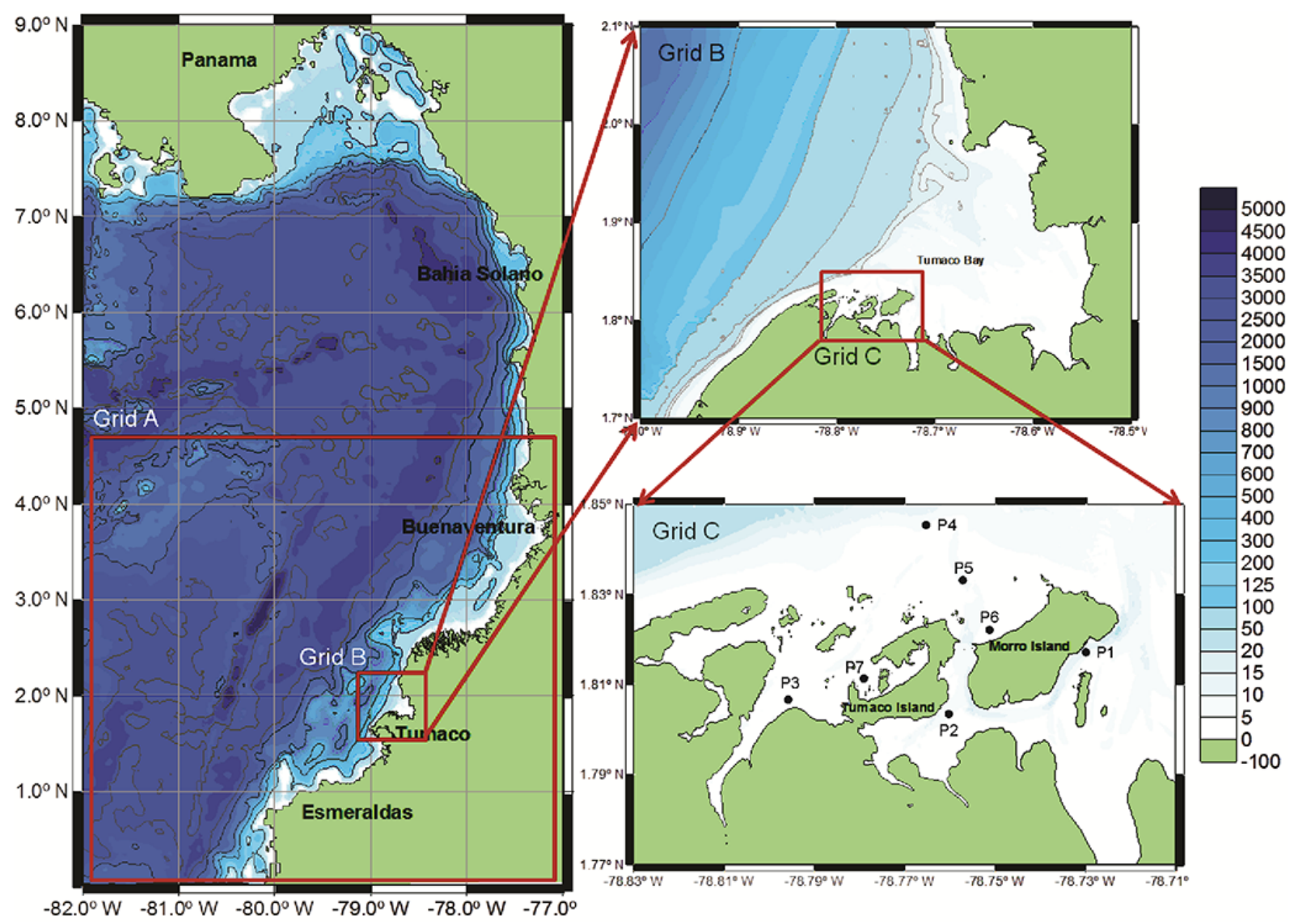

Fig. 6. Computational domain calculation meshes used in the numerical modelling of tsunamigenic events including exterior mesh (Grid A) with a spatial resolution of $450 \mathrm{~m}$, intermediate mesh (Grid B) with a spatial resolution of $150 \mathrm{~m}$, and detailed mesh (Grid C) with a spatial resolution of $30 \mathrm{~m}$. In Grid C, P1-P7 designate recording points.

where $E$ is the total energy per unit area, given by $E=\frac{\rho g H^{2}}{8}$ and $C$ is the wave celerity given by $\sqrt{g h} . \rho$ is the density of sea water, $g$ is the gravitational acceleration, $H$ is the wave height and $h$ is the depth. The relationship between the energy flux of the situation with Barrier Island $\left(E_{\mathrm{f} 1}\right)$ and without Barrier Island $\left(E_{\mathrm{f} 2}\right)$ in the same point, can be expressed approximately as

$$
\frac{E_{\mathrm{f} 1}}{E_{\mathrm{f} 2}} \approx \frac{H_{1}^{2}}{H_{2}^{2}}
$$

The ratio of the energy flux with and without the presence of the island allowed an understanding of the protection against the effects of a tsunami afforded Tumaco by the presence of El Guano Island and an assessment of the effects of the absence of the island on current geomorphology and bathymetry.

\section{Results}

\subsection{9 tsunami simulation}

Figure 7 shows the ratio of the energy fluxes simulated in the presence and absence of El Guano Island and associated with the speed and maximum wave height reached at the recording points adjacent to inhabited areas (2, 3, 6 and 7; Fig. 6). The numerical results show that the presence of El Guano Island can reduce the energy flux by 50 to $60 \%$ for sectors 3 and 7 and by $15 \%$ for sectors 2 and 6 , the areas with the highest concentration of inhabitants. According to these results, El Guano Island dissipated much of the wave energy of the 1979 tsunami and, for this reason, lessened the enormity of the disaster. Figure 8 shows the simulation results for a $3.6 \mathrm{~m}$ tide level, which demonstrate that, at present, the most critical condition for Tumaco occurs when a tsunamigenic event coincides with a full or high tide. Under this condition, most of the inhabited areas would be flooded. 


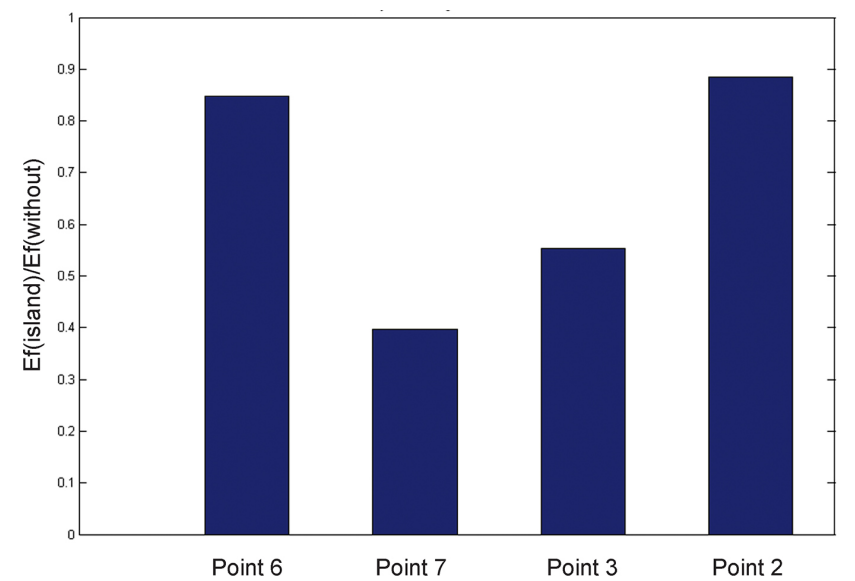

Fig. 7. Reduction of energy flux for the 1979 event in the presence of El Guano Island, Ef (island), and without the island, Ef (without).

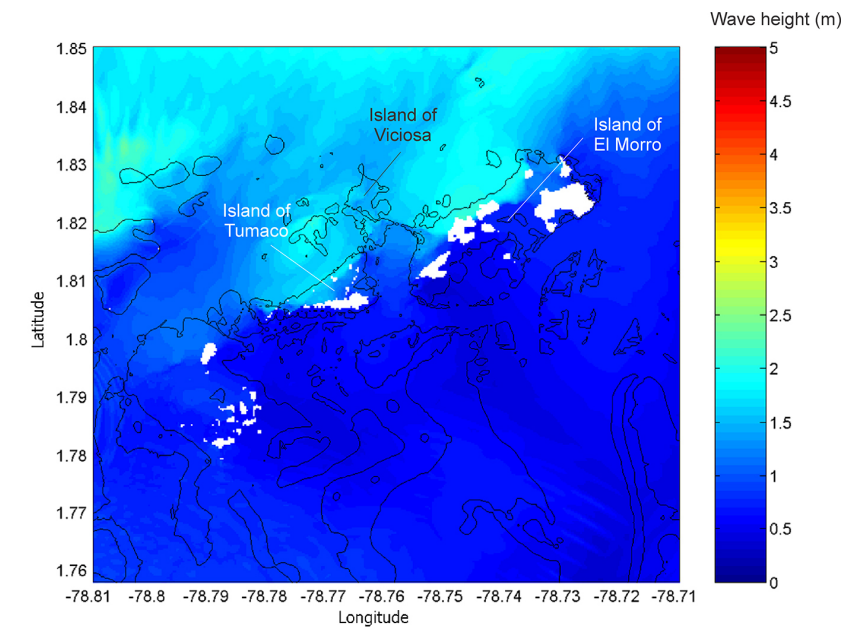

Fig. 8. Maximum flooding for an $M_{\mathrm{W}}=7.9$ earthquake and a $3.6 \mathrm{~m}$ tide level under present conditions. The black line represents the shoreline, and the white spots show unflooded areas.

\subsection{Numerical simulation of future events (based on the 1906 tsunami)}

The numerical simulations of future events considered these events as occurring under current bathymetric and geomorphological conditions in the presence and the absence of $\mathrm{El}$ Guano Island. Figure 9 shows the maximum flood in Tumaco for a tsunami like that of 1906 but occurring under current circumstances at high tide in the absence of the barrier island of El Guano (Fig. 9a) and in the presence of such an island (Fig. 9b). The results show that under the worst credible tsunami scenario for this area, the islands that compose Tumaco become completely flooded in the current situation. Moreover, the results show that the presence of El Guano Island would prevent flooding in some areas that could serve as evacuation and security zones for the population.
Figure 10 shows the relationship between the energy fluxes (with and without an island) for each tsunami source, in the recording points adjacent to inhabited areas (2, 3, 6 and 7). These results show that the El Guano barrier island can function to dissipate the tsunami wave energy flux that reaches Tumaco, especially at points 3 and 7, which are within the most populated areas. Events generated in zones IV, VI and VII would not be the most destructive in the current circumstances (Fig. 11a). The highest flood level would occur with tsunamigenic events generated in Zones I, II, III and V.

According to the data of the geotectonic and seismic analysis and the energy release sequence (from south to north), it is expected that the next event will be generated in zone II, III, V or VI. Although an event generated in Zone I would cause the most destruction, an event generated in Zone II, III or $\mathrm{V}$ seems more likely given the energy release sequence. An event generated in Zone II in the current situation would produce greater flooding of the Tumaco urban area than one generated in Zone III or V (Fig. 11a).

According to the model, the original conformation of El Guano Island largely mitigates the effects of tsunamis on the islands of Tumaco. However, this protection is inadequate for the area near point 6 (Fig. 11b). For this reason, we propose two geometric modifications to the old El Guano Island to estimate their effects on the dissipation of tsunami energy (Fig. 12). For the numerical simulation using both modifications of the barrier island geometries, Zone II was selected as a tsunami generating source under the worst credible scenario, i.e. an earthquake of $M_{\mathrm{w}}=8.6$ magnitude and a $3.6 \mathrm{~m}$ sea level.

Figure 13 shows the maximum flooding in Tumaco for a tsunami like that of 1906 but including a high tide and considering the situation with the El Guano barrier island elongated (Fig. 13a) or divided into three sections (Fig. 13b). Figure 14a shows the relationship of the energy fluxes for the modified geometries of the island (Ef) and for the original El Guano Island (Ef 1979) with the maximum wave height reached at the recording points adjacent to inhabited areas (2, 3, 6 and 7). The greatest reduction in the energy flux of tsunami waves compared with that caused by the original geometry of El Guano Island is $30 \%$ near point 6 when three islands with similar characteristics are placed in front of Tumaco. For points 2, 3 and 7, the dissipative effect is nearly the same as that for the original El Guano Island. For the conformation with three barrier islands, the flood level does not exceed $6 \mathrm{~m}$ (Fig. 14b) at points 2 and 3. At point 6, despite remaining above a +6.0 elevation, flooding is reduced by $1.5 \mathrm{~m}$. The proposed changes to the original conformation of El Guano Island do not change the flood level at point 7.

From the above results, it is observed that the elongated shape of the El Guano Island and placement of a three barrier islands with similar features reduce the energy flux of tsunami waves. Of the two alternatives to the original geometry, the three-island alternative dissipates more energy at point 6 . 

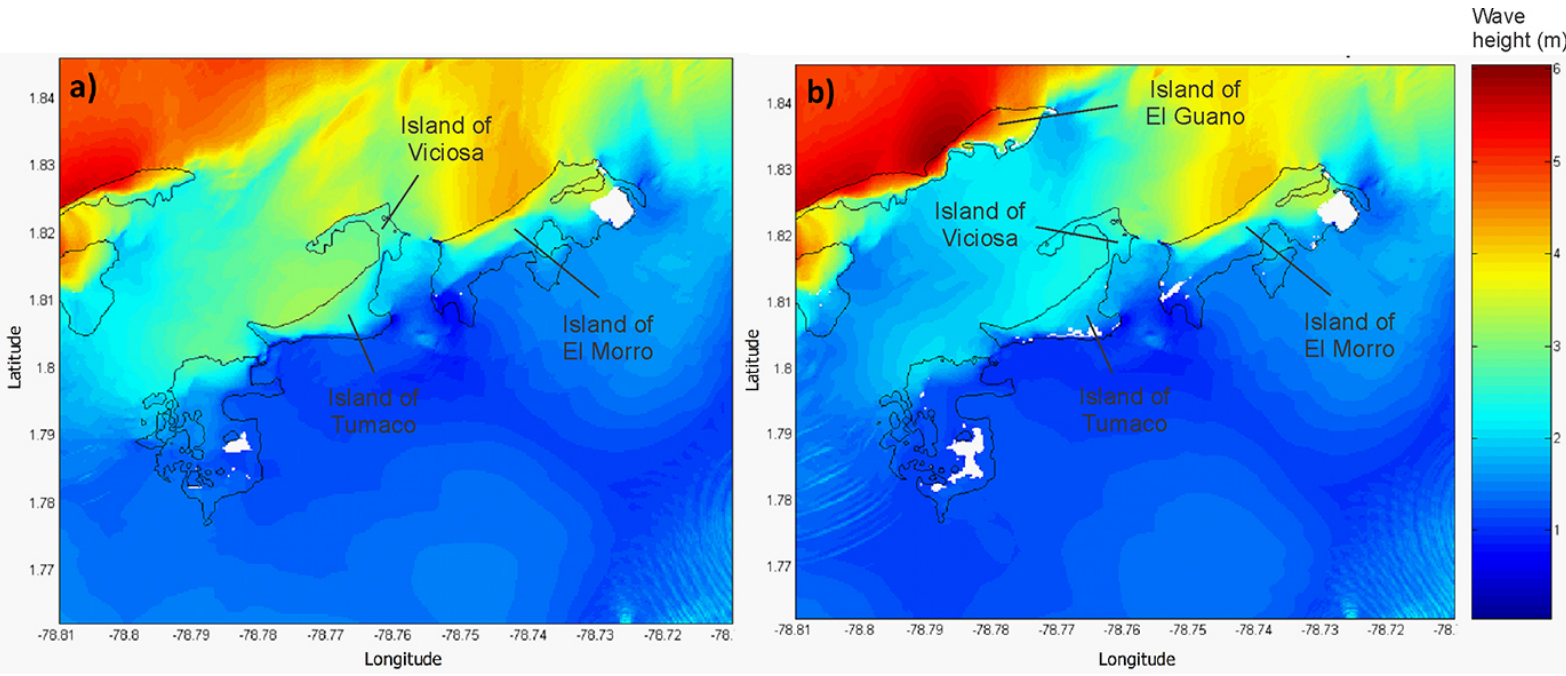

Fig. 9. Maximum flood under current situation for an $M_{\mathrm{w}}=8.6$ earthquake with a $3.6 \mathrm{~m}$ tide without El Guano Island (a) and with El Guano Island (b). The black line represents the shoreline, and the white spots show unflooded areas.

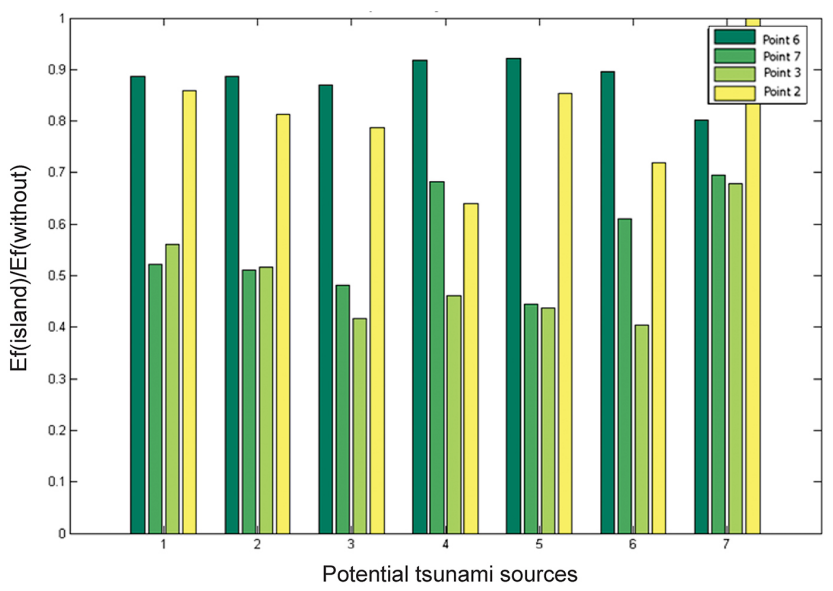

Fig. 10. Relationship between energy fluxes in the presence of El Guano Island, Ef (island), and without the island, Ef (without) according to the tsunami source and recording point.

\section{Discussion and conclusions}

Recent studies indicate that different natural systems, such as beaches, dunes, mangroves, coral fields or groves, considerably mitigate the effects of tsunamis (i.e. Tanaka et al., 2006, 2007; Tanaka, 2009). For Tumaco and the people inhabiting the Mira River delta, the adverse effects of the tsunamis that have occurred (1906, 1933, 1942, 1958 and 1979) have been attenuated by the barrier island complex located northeast of the delta as well as by the extensive intertidal flat formed during low tide. The stability and recent evolution of the Mira River delta are determined by the presence of active faults that are responsible for high shallow and intermediate seismicity and differential tectonic block displacements (Correa,
1996). These shifts affect the gradient of the deltaic plain and the slope of the continental shelf and the prodelta configuration controlling the development and orientation of distributaries, the intensity of marine processes affecting the delta front, and the preservation of submarine canyons through which a proportion of the continental sediments potentially can escape towards the ocean (Correa, 1996; Restrepo and Lopez, 2008). Particularly around Morro Island (Tumaco), the concentration of suspended sediment is controlled by littoral drift processes and the resuspension of fine particles (Restrepo and Pierini, 2011). During periods of tidal flow, the current velocity increases and net flow is created towards the continent. These flows carry suspended sediment produced in the main discharge system of the Mira River and have defined the barrier island system located to the northeast of the delta (Restrepo and Lopez, 2008). Although ebb currents are of similar magnitude to those that cause resuspension processes, they are limited by the compaction of the sediments deposited, flocculation processes, and a moderate wave energy environment (Restrepo and Pierini, 2011). A sedimentary budget developed by Molares (2008) between 2005 and 2007 indicated that Morro Island has a positive sediment flow, which is controlled by river inputs from the Mira River. Therefore, Morro Island is an environment for capturing platform sediments transported by littoral drift.

The active morphodynamics of this area, which are characterised by a moderately high marine power, high river discharge, and the migration and formation of barrier islands (Restrepo and Lopez, 2008; Restrepo and Pierini, 2011), enables the consideration of tsunami hazard assessment scenarios that include the existence of barrier island systems as mechanisms to attenuate and dissipate the energy generated by a tsunami. The information produced by this approach leads to more alternatives for mitigation and risk reduction 

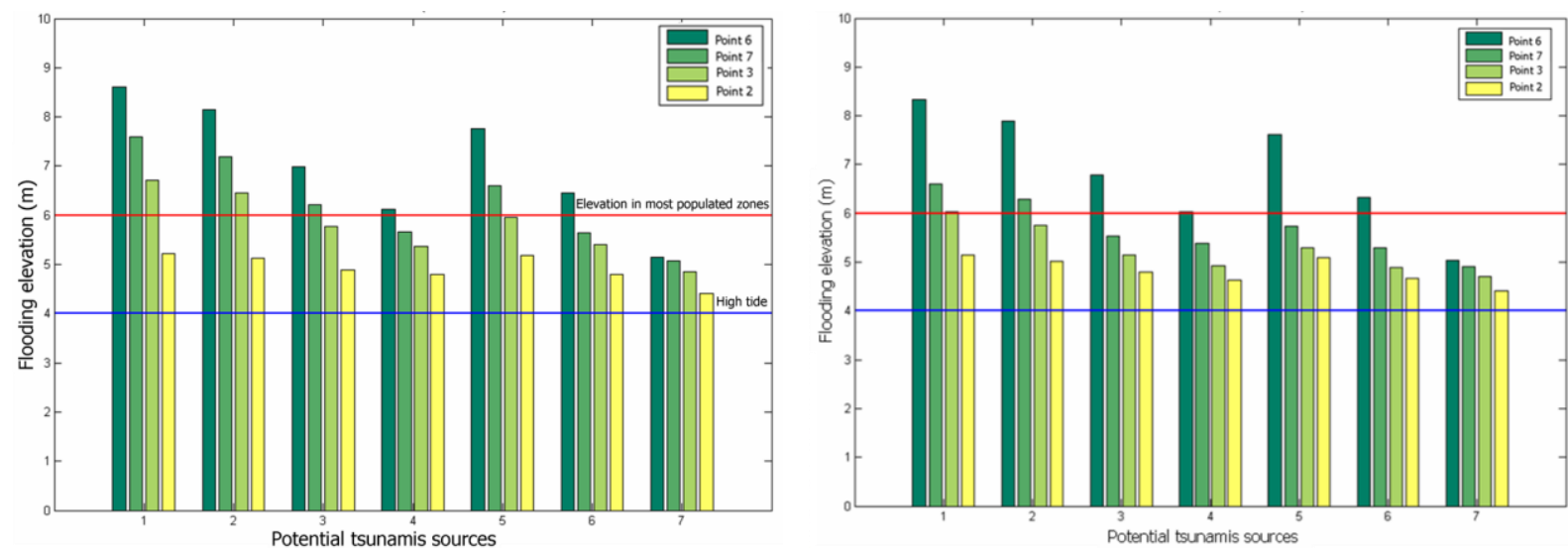

Fig. 11. Flooding level in the current situation without (left) and with (right) El Guano Island.
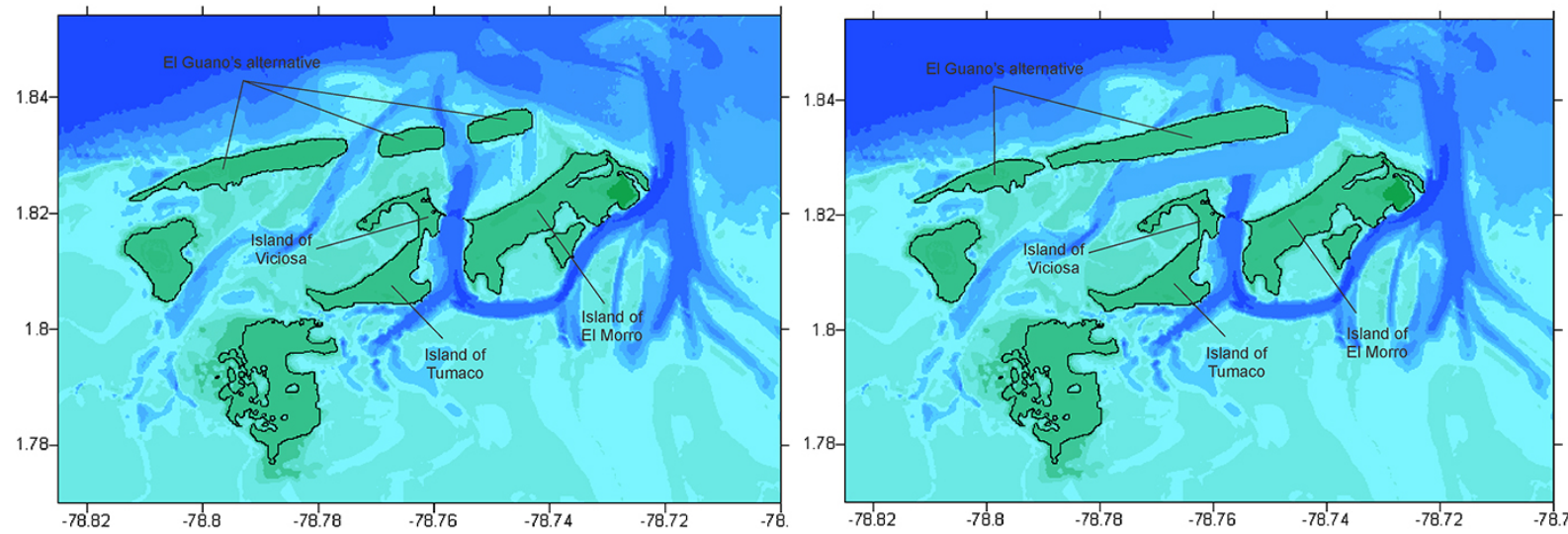

Fig. 12. The barrier island of El Guano elongated and divided into three sections.

against hazards (i.e. safe zones, the percentages of affected areas, additional evacuation routes and infrastructure protection) than that provided by a traditional approach, which only contemplates tsunami generation and wave propagation scenarios.

Historical records of tsunamis that have affected the Colombian-Ecuadorian Pacific coast over a period of more than 100 years and modelled flood scenarios confirm that the tsunami hazard in this region is high and likely. The two most active tectonic systems in the Colombian Pacific that could generate earthquakes triggering tsunami waves are the Panama fault and the subduction zone created by the Nazca plate and the South American plate; however, the rupture mechanism present in the Panama fault, which is a tear fault, does not cause a disturbance in the water column capable of generating tsunami waves. Therefore, the subduction zone that runs parallel to the Colombian Pacific coast is the main source of nearby tsunamis (Quiceno and Ortiz, 2001; Cardona et al., 2005; Restrepo and Otero, 2007). During the history of the Colombian-Ecuadorian Pacific coast, the region north of the Carnegie Ridge between 0 and $4^{\circ} \mathrm{N}$ is the most seismically active area in which tsunamis affecting Tumaco
Bay have been generated near the bay. In this area, a spatial sequence of earthquakes (from south to north) along two parallel lines following the subduction zone was established, and these lines have identified seven potential zones likely to generate nearby tsunamis.

The results of the numerical modelling of tsunamis show that during coastal flooding, tsunami waves are superimposed on tidal waves, a condition that modulates the extent and magnitude of the flood. The tidal regime in the bay of Tumaco reaches highs up to $4 \mathrm{~m}$, which explains why the coincidence of tsunami waves with high, medium, or low flood tides generates completely different flood zones, ranging from mild to disastrous floods. At low tide, the intertidal zone, which reaches a width of up to $500 \mathrm{~m}$ in some cases, becomes a dissipation area for tsunami wave energy.

The average time required by tsunami waves to travel from their origin to the town of Tumaco is 20 to 35 minutes, which highlights the short period available for residents to evacuate and for authorities to implement early warning and alarm systems. The brevity of this period explains why response plans should be simple, effective and accurate. 

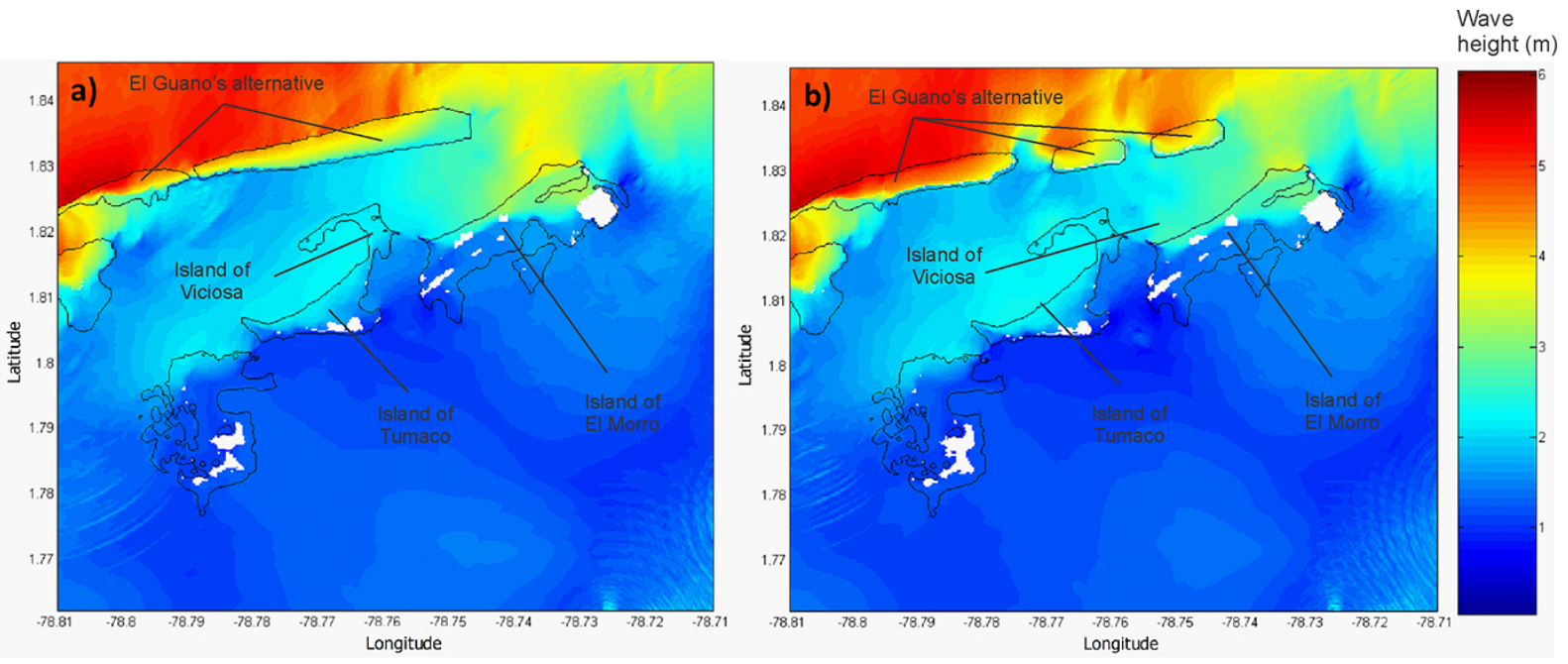

Fig. 13. Maximum flooding for an $M_{\mathrm{W}}=8.6$ earthquake with a $3.6 \mathrm{~m}$ tide level in the current situation with El Guano Island (a) elongated and (b) in three segments. The black line represents the shoreline, and the white spots show unflooded areas.
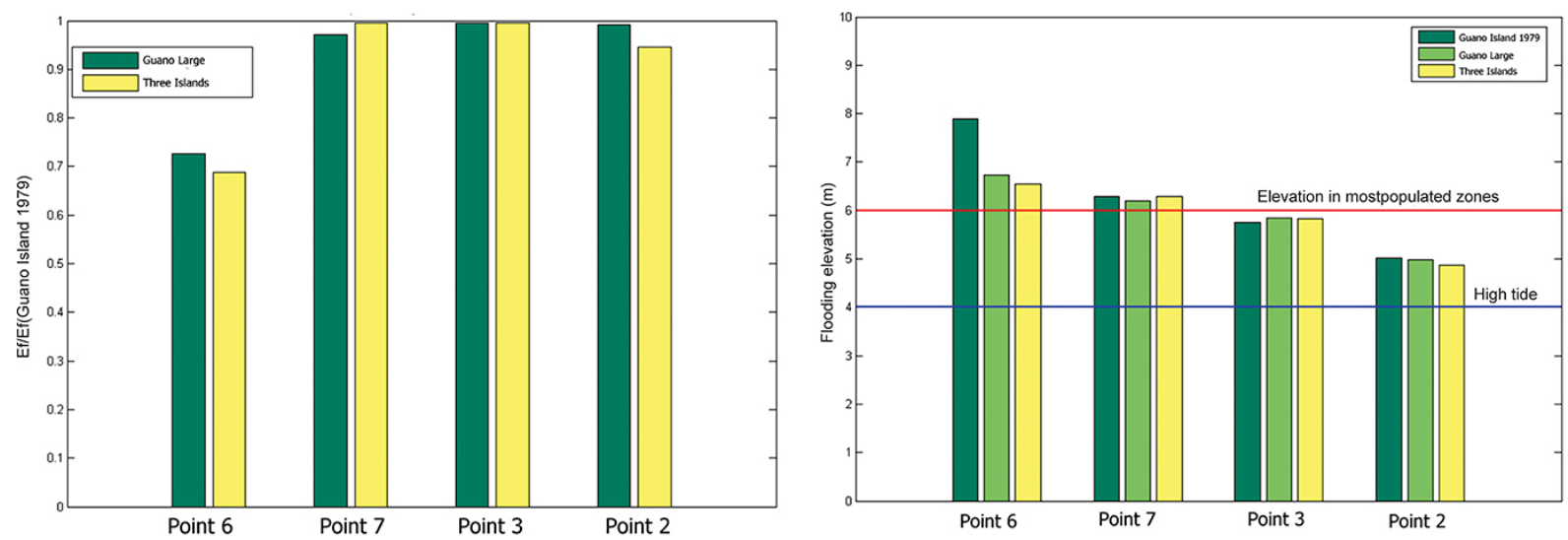

Fig. 14. Ratio of the energy flux of each modified island geometry (Ef) to that of the original conformation of El Guano Island (Guano Island 1979) (a) and flood level in the most populated areas of Tumaco for the different island geometries (b) at four locations.

In the worst credible scenario selected, which matched the 1906 tsunami, the precursor quake had a magnitude of $M_{\mathrm{w}}=8.6$, the arrival of the tsunami waves on the coast coincided with high tide and reached maximum heights of $4.5 \mathrm{~m}$, and the flooded area was covered by an average water column $3 \mathrm{~m}$ high. This scenario would be utterly disastrous if it occurred today. By contrast, an event similar to the 1979 tsunami (low tide) would not cause considerable tsunami damage to the urban area of Tumaco because the tide conditions would prevent the water levels from exceeding the maximum tide level. However, if the same event were to happen at high tide, the flood would extend over large areas of the islands that compose Tumaco and reach maximum heights of $2 \mathrm{~m}$; therefore, the tide level affects the spread and subsequent flooding of the coastal area. This result indicates that moderately intense events can cause extensive damage during high tides. In this sense, tide level is a critical factor that compounds the effects of tsunamis in meso- and macrotidal zones. For the Colombian-Ecuadorian Pacific, the sea-level condition defines a flood or nonflood situation for the same event, even for earthquakes with magnitudes $M_{\mathrm{W}}<7.9$.

The assessment of the tsunami hazard in Tumaco indicates that flooding the entire area results in conditions sufficient to produce loss of life, necessitating the implementation of substantive protective measures that do not generate a false sense of security. The simulation of the 1979 tsunami event, the historical bathymetry and geomorphology of the time, including those applicable to El Guano Island, and eyewitness accounts at the time of the event, indicated that this island reduced the effects of the tsunami on Tumaco. In the simulations for the current situation with the original El Guano barrier island and the worst credible tsunami event $\left(M_{\mathrm{w}}=8.6\right.$ and sea level $=3.6 \mathrm{~m}$ ), the island confers a significant reduction in the height of the floodwater. However, the reduction 
is insufficient to prevent the flooding of urban areas because the town of Tumaco lies on a low coastal plain. However, reductions in energy flux reaching $60 \%$ have been recorded at some points, which might be attributable to the presence of the island; therefore, rebuilding the island is considered viable for mitigating the effects of tsunamis. El Guano Island, as such, would protect much of Tumaco; however, because of the size and location of the city, unprotected areas would remain.

After analysing different barrier island geometries, the present study determined that the regeneration of El Guano Island combined with the northwards extension of its original configuration would improve coastal protection against the effects of tsunamis. The determination of the beach width and length, berm height, and number of islands in the area of the original El Guano Island must be accompanied by a coastal morphodynamics study to ensure the stability and functionality of these islands. In addition, an environmental impact study is needed to determine the effect of the island or islands on the regeneration of area beaches, on biological species, on water quality, and on the physicochemical conditions thereof. The high socioeconomic costs involved in relocating the threatened population, the proximity of the tsunami source, the absence of nearby highlands, and the difficulty of establishing a massive evacuation plan all demand means to reduce the tsunami risk to the inhabitants. These factors make the restoration of the original barrier island of El Guano a viable and realistic alternative for creating an effective, useful and efficient barrier to mitigate the impact of tsunamis on the city of Tumaco.

Acknowledgements. The authors thank the Colombian Maritime Directorate (DIMAR by its initials in Spanish) and the University of Cantabria for their support of this research study.

Edited by: S. Tinti

Reviewed by: two anonymous referees

\section{References}

Álvarez-Gómez, J. A., Gutiérrez Gutiérrez, O. Q., AnielQuiroga, Í., and González, M.: Tsunamigenic potential of outer-rise normal faults at the Middle America trench in Central America, Tectonophysics, 574-575, 133-143, doi:10.1016/j.tecto.2012.08.014, 2012.

Baptista, M. A., Miranda, J. M., Omira, R., and Antunes, C.: Potential inundation of Lisbon downtown by a 1755-like tsunami, Nat. Hazards Earth Syst. Sci., 11, 3319-3326, doi:10.5194/nhess-113319-2011, 2011.

Beck, S. L. and Ruff, L. J.: The rupture process of the great 1979 Colombia earthquake: evidence for the asperity model, J. Geophys. Res., 89, 9281-9291, 1984.

Bernard, E. N., Mofjeld, H. O., Titov, V., Synolakis, C. E. and Gonzalez, F. I.: Tsunami: scientific frontiers, mitigation, forecasting and policy implications, Philos. T. R. Soc. A, 364, 1989-2007, 2006.

Birkmann, J., Teichman, K. v., Welle, T., González, M., and Olabarrieta, M.: The unperceived risk to Europe's coasts: tsunamis and the vulnerability of Cadiz, Spain, Nat. Hazards Earth Syst. Sci., 10, 2659-2675, doi:10.5194/nhess-10-2659-2010, 2010.

Cardona, Y., Toro, F., Vélez, J., and Otero, L.: Modelación de tsunamis en la costa pacífica colombiana: caso Bahía de Tumaco, Avances en Recursos Hidráulicos, 12, 43-54, 2005.

Collot, J. Y., Charvis, P., Gutscher, M. A., and Operto, S.: Exploring the Ecuador-Colombia Active Margin and Interplate Seismogenic Zone, EOS, Transaction, American Geophys. Union, 83, 185-189, 2002.

Collot, J. Y., Marcaillou, B., Sage, F., Michaud, F., Agudelo, W., Charvis, P., Graindorge, D., Gutscher, M., and Spence, G.: Are rupture zone limits of great subduction earthquakes controlled by upper plate structures? Evidence from multichannel seismic reflection data acquired across the northern Ecuadorsouthwest Colombia margin, J. Geophys. Res., 109, B1103, doi:10.1029/2004JB003060, 2004.

Correa, I. D.: Le littoral Pacifique colombien: Interdependancedes agents morphostructuraux et hydrodynamiques, $\mathrm{Ph} . \mathrm{D}$. thesis, Geologie Marine, Université Bordeaux I, 178 pp., 1996 (in French).

Engdahl, E. R. and Villaseñor, A.: Global Seismicity: 1900-1999, in: International Handbookof 5 Earthquake and Engineering Seismology, Part A, Chapter 41, edited by: Lee, W. H. K., Kanamori, H., Jennings, P. C., and Kisslinger, C., Academic Press, 665-690, doi:10.1016/S0074-6142(02)80244-3, 2002.

Engdahl, E. R., Van der Hilst, R. D., and Buland, R.: Global teleseismic earthquake relocation with improved travel times and procedures for depth relocation, B. Seismol. Soc. Am., 88, 722-743, 1998.

GEBCO: The GEBCO 08 Grid, version 20081212, available at: http://www.gebco.net (last access: November 2012), 2008.

Gusiakov, V. K.: Basics Pacific tsunamis catalog and database, 47 BC-2000 AD: results of the first stage of the project, in: Proceedings of the International Tsunami Symposium, 7-9 August 2001, Seattle, USA, PMEL/NOAA, 263-272, 2001.

Gutscher, M. A., Malavieille, J., Lallemand, S., and Collot, J. Y.: Tectonic segmentation of the North Andean margin: impact of the Carnegie Ridge collision, Earth Planet. Sc. Lett., 168, 255270, doi:10.1016/S0012-821X(99)00060-6, 1999.

Harvard University, Harvard Seismology-Harvard CMT Catalog, available at: http://www.seismology.harvard.edu (last access: August 2010), 2010.

Iida, K.: The generation of tsunamis and the focal mechanisms of earthquakes, in: Tsunamis 25 in the Pacific Ocean, edited by: Adams, W. M., East-West Center Press, Honolulu, Hawaii, 3-18, 1970.

Kanamori, H. and Anderson, D. L.: Theoretical basis of some empirical relations in seismology, B. Seismol. Soc. Am., 65, 10731095, 1975.

Lima, V. V., Miranda, J. M., Baptista, M. A., Catalao, J., Gonzalez, M., Otero, L., Olabarrieta, M., Álvarez-Gómez, J. A., and Carreño, E.: Impact of a 1755-like tsunami in Huelva, Spain, Nat. Hazards Earth Syst. Sci., 10, 139-148, doi:10.5194/nhess10-139-2010, 2010.

Liu, P., Cho, Y., Yoon, S., and Seo, S.: Numerical simulations of the 1960 Chilean tsunami propagation and inundation at Hilo, 
Hawaii, in: Recent development in tsunami research, edited by: El-Sabh, M. I., Kluwer Academic, Dordrecht, The Netherlands, 99-115, 1994.

Liu, P., Cho, Y., Briggs, M. J., Kanoglu, U., and Synolakis, C. E.: Runup of solitary waves on a circular island, J. Fluid Mech., 302, 259-285, 1995.

Mendoza, C. and Dewey, J. W.: Seismicity associated with the great Colombia-Ecuador earthquakes of 1942, 1958, and 1979: implications for barrier models of earthquake rupture, B. Seismol. Soc. Am., 74, 577-593, 1984.

Mimura, N., Yasuhara, K., Kawagoe, S., Yokoki, H., and Kazama, S.: Damage from the Great East Japan Earthquake and Tsunami - A quick report, Mitig. Adapt. Strategies Glob. Chang., 16, 803818, doi:10.1007/s11027-011-9297-7, 2011.

Molares, B.: Impactos de los deltas en la seguridad y transporte marítimo: sedimentación en la bahía de Tumaco, delta del río Mira, in: Los Deltas de Colombia: Morfodinámica y Vulnerabilidad ante el Cambio Global, edited by: Restrepo, J. D., Fondo Editorial Universidad, Medellín, EAFIT, 208-217, 2008 (in Spanish).

Okada, Y.: Surface deformation due to shear and tensile faults in a half-space, B. Seismol. Soc. Am., 75, 1135-1154, 1985.

Omira, R., Baptista, M. A., and Miranda, J. M.: Evaluating tsunami impact on the Gulf of Cadiz coast (Northeast Atlantic), Pure Appl. Geophys., 168, 963-968, 2011.

Otero, L. and González, E.: Regeneración de la Isla Barrera el Guano como un elemento protector de Tumaco frente a la acción de tsunamis, evaluación preliminar, in: Proceedings of XXI Congreso Latinoamericano de Hidráulica, International Association for Hydraulic Research and Engineering (IAHR), Sao Pedro, Brazil, 283-294, 2004 (in Spanish).

Otero, L. and Restrepo, J. C.: Modelamiento Numérico y Dinámico en Deltas: Aplicación de Modelos Hidrodinámicos para el Análisis Oceanográfico del Delta del Río Mira, in: Los Deltas de Colombia: Morfodinámica y Vulnerabilidad ante el Cambio Global, edited by: Restrepo, J. D., Fondo Editorial Universidad EAFIT, Medellín, Colombia, 220-237, 2008 (in Spanish).

Quiceno, A. and Ortiz, M.: Evaluación del impacto de un tsunami en el litoral Pacífico colombiano (región de Tumaco), Boletín Científico CCCP, Boletín Científico del Centro de Control de Contaminación del Pacífico, 8, 5-14, 2001 (in Spanish).

Ramírez, J. and Goberna, J.: Terremotos colombianos: noviembre 23 y diciembre 12 de 1979-Informe preliminar, Reporte Técnico, Instituto Geofísico de la Universidad Javeriana, Bogotá, 95 pp., 1980 (in Spanish).

Restrepo, J. D. and López, S.: Morphodynamics of the Pacific and Caribbean deltas of Colombia, South America, J. S. Am. Earth Sci., 25, 1-21, 2008.

Restrepo, J. C. and Otero, L.: Modelación numérica de eventos tsunamigénicos en la Cuenca Pacífica Colombiana - Bahía de Buenaventura, Revista de la Academia Colombiana de Ciencias Exactas, Físicas y Naturales, 31, 363-377, 2007 (in Spanish).
Restrepo, J. C. and Pierini, J. O.: Medición de la concentración de sedimentos en suspensión mediante dispositivos ópticos (OBS 3A) y acústicos (AWAC ADCP): aplicación en sistemas tropicales (Delta del Río Mira), Lat. Am. J. Aquat. Res., 40, 153-168, doi:10.3856/vol40-issue1-fulltext-15, 2012 (in Spanish).

Restrepo, J. C., Otero, L., López, S., and Monroy, C.: Los Deltas y el Oleaje, caso Delta del Río Mira: Estadísticas, Clima, Corrientes, Energía y Procesos de Asomeramiento, in: Los Deltas de Colombia: Morfodinámica y Vulnerabilidad ante el Cambio Global, Fondo Editorial Universidad EAFIT, 182-205, doi:10.3856/vol40-issue1-fulltext-15, 2008a (in Spanish).

Restrepo, J. C., Otero, L., and López, S.: Clima de Oleaje en el Pacífico Sur de Colombia, delta del Río Mira: Comparaciones Estadísticas y Aplicación a Procesos Costeros, Revista de la Academia Colombiana de Ciencias Exactas, Físicas y Naturales, 33, 339-357, 2008b (in Spanish).

Swenson, J. L. and Beck, S. L.: Historical 1942 Ecuador and 1942 Peru subduction earthquakes, and earthquake cycles along Colombia-Ecuador and Peru subduction segments, Pure Appl. Geophys., 146, 67-101, 1996.

Synolakis, C. E. and Bernard, E. N.: Tsunami science before and after 2004, Philos. T. Roy. Soc. A, 364, 2231-2265, doi:10.1098/rsta.2006.1824, 1996.

Tanaka, N.: Vegetation bioshields for tsunami mitigation: review of effectiveness, limitations, construction, and sustainable management, Landscape Ecol. Eng., 5, 71-79, 2009.

Tanaka, N., Sasaki, Y., and Mowjood, M. I. M.: Effects of sand dune and vegetation in the coastal area of Sri Lanka at the Indian Ocean tsunami, in: Advances in Geosciences, edited by: Namsik Park, 6, World Scientific Publishing Co, Singapore, 2006.

Tanaka, N., Sasaki, Y., Mowjood, M. I. M., and Jinadasa, K. B. S. N.: Coastal vegetation structures and their functions in tsunami protection: experience of the recent Indian Ocean tsunami, Landscape Ecol. Eng., 3, 33-45, 2007.

Wang, X. and Liu, P.: A numerical investigation of BoumerdesZemmouri (Algeria) earthquake and tsunami, CMES-Comp. Model. Eng., 10, 171-183, doi:10.3970/cmes.2005.010.171, 2005.

Wang, X. and Liu, P. L.-F.: An analysis of 2004 Sumatra earthquake fault plane mechanisms and Indian Ocean tsunami, J. Hydraul. Res., 44, 147-154, doi:10.1080/00221686.2006.9521671, 2006.

Wang, X. and Liu, P. L.-F.: Numerical simulations of the 2004 Indian Ocean tsunamis - Coastal effects, J. Earthq. Tsunami, 1, 273-297, 2007.

Wells, D. L. and Coppersmith, K. J.: New empirical relationships among magnitude, rupture length, rupture width, rupture area, and surface displacement, B. Seismol. Soc. Am., 84, 974-1002, 1994.

Wiegel, R. L.: Tsunamis in Earthquake Engineering, Chapter 11, Prentice Hall, Englewood Cliffs, NJ, 253-306, 1970. 